\title{
Urgensi Re-Desain Penyelenggaraan Pilkada dengan Satu Pasangan Calon Berdasarkan Dinamika Implementasi di Jawa Tengah dalam Perspektif Pengawasan
}

\section{The Urgency of Redesigning Single-Pair Candidate Election Based on Dynamics Implementation in Central Java From Electoral Supervisory's Perspective}

\author{
Inti Priswari \\ Bawaslu Provinsi Jawa Tengah \\ Jl. Papandayan Selatan No. 1 Semarang \\ E-mail: \\ i.priswari@gmail.com
}

\begin{abstract}
This research tries to unravel the patterns that emerge from implementing single-pair candidate elections from electoral supervisors' perspective in Central Java. The aim is to identify the problems of the election, particularly from the electoral supervisory's point of view. This descriptive qualitative research using the online interview as a primary data collecting method added with a questionnaire and supervisory report as secondary data finds some regulatory gaps regarding the "subject" and "activity" of empty columns. The gap has been the main factor in the issues of the electoral supervisory elections with the single-pair candidate. Moreover, if these gaps are not addressed promptly, it will become an ongoing problem that will re-emerge and even escalate into widespread horizontal conflict. Therefore, it is necessary to redesign the electoral institution of single-pair candidates comprehensively to suppress various potential problems.
\end{abstract}

Keywords: empty column; contestation; electoral supervisory; local election; single candidate pair

\section{Abstrak}

Penelitian ini mencoba mengurai pola permasalahan yang muncul dari implementasi penyelenggaraan pilkada dengan satu pasangan calon dalam perspektif pengawasan di Jawa Tengah. Tujuannya adalah untuk melakukan identifikasi permasalahan penyelenggaraan pilkada dengan satu pasangan calon utamanya dari sudut pandang pengawasan. Penelitian yang bersifat deskriptif kualitatif dengan teknik pengumpulan data primer melalui wawancara secara daring serta ditunjang melalui kuesioner untuk melengkapi kekurangan data teknis dan analisis atas laporan pengawasan sebagai data sekunder ini menemukan adanya celah kekosongan regulasi yang mengatur tentang "subjek" dan "aktivitas" kolom kosong. Dimana celah ini selanjutnya menjadi faktor utama dalam persoalan penyelenggaraan pengawasan dalam pilkada dengan satu pasangan calon. Melihat dari kecenderungan fenomena yang ada, bila hal ini terus dibiarkan dapat berpotensi menjadi persoalan yang terus berulang dan bahkan dapat bereskalasi menjadi konflik horizontal yang meluas. Karenanya perubahan desain penyelenggaraan pilkada satu pasangan calon secara lebih komprehensif perlu dilakukan untuk dapat menekan berbagai potensi permasalahan yang ada.

Kata Kunci: kolom kosong; kontestasi; pengawasan; pilkada; satu pasangan calon 


\section{Pendahuluan}

Politik hukum pemilu di Indonesia kian berkembang pasca reformasi, salah satunya melalui terwujudnya pemilihan kepala daerah (Pilkada) secara langsung sejak tahun 2005. Penguatan demokrasi ini tentunya menjadi capaian signifikan bangsa Indonesia dalam menyalurkan hak untuk memilih dan dipilih. Melalui Pilkada, warga negara diberikan sarana untuk menyeleksi kepemimpinan dengan secara langsung menentukan pemimpin di tingkat lokal.

Marijan (2010) mengemukakan bahwa penyelenggara pilkada ini diharapkan dapat mereduksi pembajakan kekuasaan yang dilakukan oleh partai-partai politik pemilik kursi di Dewan Perwakilan Rakyat Daerah (DPRD). Semangat pelaksanaan Pilkada langsung ini adalah untuk mengembalikan hak politik rakyat yang selama ini hanya dilakukan melalui perwakilan di DPRD.

Dalam perkembangannya, banyak perubahan terjadi pada tata kelola penyelenggaraan pilkada. Tak hanya munculnya kesempatan bagi calon perseorangan dan desain penyelenggaraan pilkada serentak dalam lima gelombang, namun juga diakomodasinya satu pasangan calon atau juga dikenal sebagai calon tunggal dalam pilkada tahun 2015. Mahkamah Konstitusi melalui Putusan Nomor 100/PUU-XIII/2015 mendalilkan eksistensi pilkada dengan satu pasangan calon tersebut.

Putusan itu merupakan jalan mengatasi kebuntuan dari persoalan tidak terpenuhinya syarat minimal dua pasangan calon kepala daerah untuk berkompetisi dalam pilkada. MK menilai bahwa Undangundang mengamanatkan pilkada sebagai pelaksanaan kedaulatan rakyat, maka demi menjamin terpenuhinya hak konstitusional warga negara, pilkada tetap harus dilaksanakan meski hanya terdapat satu pasangan calon setelah melalui proses yang berlaku.

Sejak saat itu, penyelenggaraan pilkada dengan satu pasangan calon semakin tumbuh subur, sebagaimana data yang diolah dari berbagai sumber dan tersaji dalam Tabel 1. Dalam tiap perhelatan, pilkada dengan satu pasangan calon jumlahnya kian bertambah, meski hingga saat ini hanya terdapat pada pemilihan tingkat kabupaten/kota saja. Belum merambah ke pemilihan kepala daerah di tingkat provinsi.

\begin{tabular}{|c|c|c|c|c|c|c|c|c|}
\hline \multirow{2}{*}{ 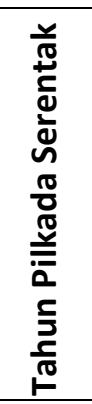 } & \multicolumn{4}{|c|}{$\begin{array}{c}\text { Jumlah Daerah } \\
\text { Penyelenggara } \\
\text { Pilkada }\end{array}$} & \multicolumn{3}{|c|}{$\begin{array}{c}\text { Daerah Pilkada } \\
\text { Satu Pasangan } \\
\text { Calon }\end{array}$} & \multirow{2}{*}{$\mid \begin{array}{l}\text { o̊ } \\
\frac{\varepsilon}{\pi} \\
\frac{\pi}{\pi} \\
0 \\
\frac{c}{\pi} \\
\frac{\pi}{\varepsilon} \\
\underline{J}\end{array}$} \\
\hline & $\begin{array}{l}\bar{n} \\
\frac{\bar{c}}{3} \\
\frac{0}{2}\end{array}$ & 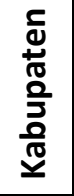 & $\begin{array}{l}\text { ֻే } \\
\stackrel{0}{0}\end{array}$ & $\frac{\frac{5}{\pi}}{\frac{\pi}{2}}$ & 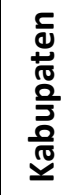 & $\begin{array}{l}\stackrel{\pi}{0} \\
\underline{0}\end{array}$ & $\frac{\frac{5}{\pi}}{\frac{\sqrt{E}}{5}}$ & \\
\hline 2015 & 9 & 224 & 36 & 269 & 3 & 0 & 3 & 1,12 \\
\hline 2017 & 7 & 76 & 18 & 101 & 6 & J & 9 & 8,91 \\
\hline 2018 & 17 & 115 & 39 & 171 & 13 & 3 & 16 & 9,36 \\
\hline 2020 & 9 & 224 & 37 & 270 & 21 & 4 & 25 & 9,26 \\
\hline
\end{tabular}

Data menunjukkan bahwa pilkada serentak tahun 2015 yang digelar di 269 wilayah, telah melahirkan pasangan calon tunggal pertama dalam sejarah dari 3 kabupaten, meski mulanya terancam mengalami penundaan pilkada. Sedangkan untuk pilkada serentak tahun 2017, dari sejumlah 101 daerah penyelenggara pilkada, terdapat 9 daerah dengan calon tunggal. Jumlah tersebut bertambah pada 
pilkada serentak tahun 2018, dari 171 daerah penyelenggara pilkada, terdapat 16 kabupaten/kota yang hanya terdapat satu pasangan calon. Sedangkan untuk pelaksanaan pilkada serentak yang terakhir diselenggarakan yaitu pilkada tahun 2020 dengan 270 daerah penyelenggara, terdapat 25 daerah dengan calon tunggal.

Berdasarkan data di atas, jumlah daerah penyelenggara pilkada dengan satu pasangan calon mengalami peningkatan signifikan. Hal ini di sisi lain tentu menimbulkan kekhawatiran tersendiri bagi perkembangan kehidupan demokrasi ke depan. Terlebih pada realitanya kemudian banyak menimbulkan dinamika baru dan persoalan teknis pelaksanaan di lapangan. Kritik atas pelaksanaan teknis pilkada dengan pasangan calon tersebut mulai bermunculan. Mayoritas kritik terkait pelaksanaan pilkada dengan satu pasangan calon adalah dengan mendasarkan dalil bahwa syarat minimal demokrasi, sebagaimana menurut Dahl dalam Marijan (2010), adalah adanya pemenuhan atas prinsip partisipasi dan kontestasi. Hal ini selaras sebagaimana juga menurut Shapiro (2006) yang mendalilkan bahwa agar kompetisi politik dapat bermakna, diperlukan penyediaan alternatif dan ada tuntutan adanya alternatif dari publik yang memiliki hak suara. Persoalan "ada" atau "tidak"nya kontestasi dalam penyelenggaraan pilkada dengan satu pasangan calon inilah yang kemudian menjadi substansi dari perdebatan para peneliti terkait kedudukan pilkada ini dalam lingkup demokrasi. Upaya dalam rangka memenuhi aspek "kompetisi" atau kontestasi ini sejatinya bukan tidak diusahakan, hadirnya "lawan tanding" untuk pasangan calon tunggal berupa kotak kosong (kolom kosong) sesungguhnya adalah salah satu aspek.

Namun kontestasi atau persaingan seringkali dianggap belum hadir dalam pelaksanaan pilkada dengan satu pasangan calon. Karena kotak kosong sebagai rival didudukkan sebagai entitas yang bersifat pasif, tidak berdaya dan cenderung hanya sebagai "aksesoris". Sehingga dalam hal ini pilkada dengan satu pasangan calon sering dinilai masih bersifat non-kontestasi.

Penyelenggaraan pilkada dengan satu pasangan calon semakin hari nampak semakin menjadi "jalan politik" yang makin diminati, tak terkecuali di Jawa Tengah. Di Jawa Tengah, penyelenggaraan pilkada dengan satu pasangan calon terus mengalami peningkatan dari sisi jumlah. Dari satu daerah pada Pilkada Tahun 2017 (Kabupaten Pati), menjadi enam daerah pada Pilkada Tahun 2020 (Kota Semarang, Kabupaten Grobogan, Kabupaten Boyolali, Kabupaten Sragen, Kabupaten Wonosobo, Kabupaten Kebumen). Dengan semakin banyaknya penyelenggaraan, berbagai persoalan di lapangan pun semakin kentara dan karenanya menarik untuk ditinjau lebih dalam.

Banyak kajian yang telah dilakukan dan sebagian diantaranya menjadi referensi tulisan ini. Mulai dari kajian yang membahas persoalan hukum pilkada dengan satu pasangan calon (paslon), kedudukan hukum kolom kosong, hingga tinjauan konsep penyelenggaraan pemilihan.

Dalam tulisan Calon Tunggal dalam Pilkada Serentak Tahun 2015 terhadap 
Putusan Mahkamah Konstitusi Nomor 100/PUU-XIII/2015 (Nazriyah, 2016), dijelaskan bahwa putusan MK (untuk dapat memilih setuju atau tidak setuju pada pilkada dengan satu paslon) merupakan sebuah upaya untuk menghindari tersanderanya hak politik publik. Selain itu MK menimbang bahwa perumusan yang mengharuskan adanya lebih dari satu paslon tidak memberikan solusi yang menyebabkan kekosongan hukum, yang berakibat tidak dapat terselenggaranya pilkada. Kajian ini lebih berfokus pada latar belakang lahirnya putusan MK tentang pemberian pilihan setuju dan tidak setuju pada pilkada dengan satu paslon. Sehingga belum banyak diuraikan mengenai pelaksanaan putusan ini di lapangan atau implikasinya bagi penyelenggaraan pemilihan.

Sementara itu terdapat sebuah ide menarik yang disampaikan dalam tulisan yang berjudul Calon Tunggal Pilkada Kurangi Kualitas Demokrasi (Kajian Putusan Mahkamah Konstitusi Nomor 100/PUUXIII/2015) (Tanjung dan Saraswati, 2019). Pada penelitian tersebut dikemukakan bahwa pilkada dengan satu paslon memerlukan konstruksi hukum yang tepat dengan cara memberikan pengetatan dukungan kepala daerah yang akan diusulkan oleh partai politik atau gabungan partai politik peserta pemilihan. Ide yang disampaikan dalam kajian ini merupakan hal yang menarik namun hanya dapat dieksekusi oleh pembuat kebijakan di level legislatif dan eksekutif, bukan di tataran penyelenggara pemilihan yang sesungguhnya merupakan pelaksana dari peraturan perundang-undangan.
Di lain sisi, tinjauan terkait legitimasi posisi kolom kosong dengan pemberdayaan peranan civil society diungkapkan dalam tulisan yang berjudul Gerakan Politik Pendukung Kotak Kosong: Keterlibatan Civil Society dalam Pilkada Kabupaten Pati Tahun 2017 (Widyasari, dkk, 2019). Penelitian ini membahas mengenai peranan civil society dalam penyelenggaraan pilkada dengan satu paslon di Kabupaten Pati Tahun 2017. Peneliti mencermati gerakan pendukung kotak kosong di Kabupaten Pati dan upaya civil society menggugat hasil pemilihan ke MK, namun belum berhasil karena civil society sebagai pemohon gugatan tidak memiliki legal standing/kedudukan hukum untuk mengajukan permohonan perselisihan penetapan perolehan suara. Kesimpulan penelitian tersebut adalah perlunya ruang hukum melalui peraturan, misalnya pada tahapan kampanye dan penyelesaian sengketa hasil pemilihan untuk mengakomodasi keterlibatan civil society. Sayangnya untuk pengaplikasian gagasan ini diperlukan tingkat keterlibatan masyarakat yang tinggi, sementara permasalahan mengenai partisipasi masyarakat dalam pemilihan sampai saat ini pun masih menjadi sebuah tantangan bagi penyelenggara.

Kajian lainnya muncul dari sudut pandang penyelenggara teknis pemilihan KPU dengan gagasan untuk menggunakan jenis pemilihan umum (pemilu) uncontested election sebagai jalan keluar dari permasalahan pilkada dengan satu paslon. Gagasan ini disampaikan dalam tulisan berjudul Pergulatan Konsep Contested Election dan Uncontested 
Election (Studi Kasus Pilkada Kabupaten Pati Tahun 2017) (Hikmania, 2019). Kajian ini membahas mengenai konsep penyelenggaraan pilkada dengan satu paslon berdasarkan studi kasus Pilkada Kabupaten Pati Tahun 2017 sebagai konsep pemilu yang melaksanakan dua ragam pemilu berbarengan, yaitu contested election dan uncontested election. Dampaknya pada tataran implementasi, penyelenggara pemilihan dan stakeholder terkait mengalami kebingungan. Kesimpulan dari penelitian tersebut, Penulis menawarkan rekomendasi untuk menerapkan jenis Pemilu uncontested election seperti yang telah digunakan di Amerika Serikat dan Filipina. Uncontested election ini mempergunakan aklamasi dengan tanpa melibatkan suara rakyat. Artinya saat paslon yang memenuhi syarat hanya satu saja, maka akan langsung terpilih tanpa melalui proses kontestasi dalam tahapan pemilihan selanjutnya.

Berdasarkan kajian tersebut, konsep ini dianggap lebih efektif baik dari segi anggaran penyelenggaraan, teknis penyelenggaraannya serta meminimalkan konflik horizontal, meski dianggap kurang demokratis. Gagasan penerapan uncontested election ini pernah ditolak MK, sehingga MK memutuskan untuk penggunaan kolom setuju dan tidak setuju sebagai wujud dari sebuah kontestasi. Penerapan uncontested election ini juga dikhawatirkan akan sulit diterima oleh semua masyarakat karena minimnya partisipasi publik.

Namun dari kajian-kajian yang telah dibahas tersebut, tidak banyak yang membahas dan mengkaji dari sisi penyelenggaraan

Padahal pada pelaksanaan penyelenggaraan pilkada dengan satu paslon, pengawas menghadapi dinamika tidak hanya pada implementasi teknis namun juga pengawasan dan penindakannya. Yang perlu dipahami adalah dimensi pengawasan yang dijalankan jajaran pengawas tidaklah berkurang atau disesuaikan jumlah paslon yang berkompetisi. Karena hakikatnya, dimensi pengawasan tidak hanya paslon sebagai peserta pemilihan saja namun juga meliputi banyak hal, seperti unsur-unsur pihak yang wajib netral dalam pemilihan, para pemilih, serta proses penyelenggaraan teknis yang dijalankan semua jajaran KPU.

Di lain sisi, kajian ini juga dapat memberikan perspektif lain dalam rangka mendukung hasil penelitian sebelumnya, utamanya kajian yang ditulis Hikmania (2019) yang sekalipun berbeda sudut pandang tetapi memiliki keresahan yang sama terkait teknis penyelenggaraan tahapan pilkada dengan satu paslon yang ada saat ini.

Latar belakang kajian ini adalah adanya kesenjangan kenyataan empiris yaitu semakin banyaknya jumlah daerah penyelenggara pilkada dengan satu paslon, dengan masih sedikitnya jumlah kajian yang secara serius membahas implementasi teknis penyelenggaraannya di lapangan.

Oleh karena itu, kajian ini mencoba mengurai pola-pola yang muncul dari implementasi penyelenggaraan pengawasan pilkada dengan satu paslon, utamanya di Jawa Tengah. Perspektif 
pengawasan perlu diangkat karena bagaimanapun adanya lembaga pengawas secara formal dalam pelaksanaan demokrasi di Indonesia, dapat memberikan sumbangan teoritis bagi khazanah tata kelola pemilu. Di lain sisi, Jawa Tengah menjadi menarik sebagai lokus kajian karena seringkali dijadikan barometer suksesnya pelaksanaan elektoral demokrasi di Indonesia, selain dikarenakan merupakan salah satu provinsi dengan jumlah pemilih terbanyak, juga menunjukkan adanya kecenderungan peningkatan kontestasi pemilihan dengan satu paslon secara signifikan. Selain itu, hampir di setiap daerah Jawa Tengah yang menggelar pemilihan dengan satu paslon diikuti dengan munculnya relawan kolom kosong yang dapat diartikan bahwa sebagian masyarakat menghendaki adanya pilihan lain selain paslon yang telah ditetapkan. Tentunya hal ini akan menarik untuk dikaji mengingat bahwa penyelenggaraan pengawasan merupakan bagian yang tidak terpisahkan dalam menghadapi dinamika penyelenggaraan pemilihan di Indonesia. Harapannya, melalui tulisan ini dapat dilakukan identifikasi permasalahan penyelenggaraan pilkada dengan satu paslon dari sudut pandang pengawasan. Sehingga hasil dari tulisan ini selanjutnya dapat menjadi bahan masukan dalam merumuskan perbaikan desain tata kelola penyelenggaraan pilkada dengan satu paslon.

\section{Metode Penelitian}

Penelitian ini menggunakan metode kualitatif dalam pengumpulan dan pengolahan data. Metode penelitian kualitatif ini dapat digunakan untuk mengungkap dan memahami sesuatu di balik fenomena (Strauss \& Corbin, 2003). Teknik pengumpulan data primer dilakukan dengan wawancara secara daring (melalui media percakapan daring) dengan beberapa tokoh kunci dalam penyelenggaraan pengawasan serta diperkuat dengan kuesioner yang diberikan untuk menunjang data hasil wawancara. Selanjutnya kajian ini didukung dengan data sekunder yang bersumber dari laporan tertulis Badan Pengawas Pemilihan Umum (Bawaslu) Kabupaten/Kota yang menyelenggarakan pilkada dengan satu paslon di Jawa Tengah. Teknik analisis data menggunakan proses analisis data hasil wawancara, kuesioner dan laporan tertulis. Informan pada penelitian ini adalah Koordinator Divisi PHL (Pengawasan dan Hubal) dari 7 Bawaslu Kabupaten/Kota penyelenggara Pilkada dengan calon tunggal di Jawa Tengah. Adapun ruang lingkup penelitian yakni kabupaten/kota penyelenggara pilkada dengan satu paslon di Provinsi Jawa Tengah.

\section{Perspektif Teori}

\section{Pemilihan Demokratis}

Pemilihan umum merupakan instrumen penting dalam demokrasi. Melalui pemilihan umum, mekanisme untuk menjalankan rotasi kekuasaan berbasis pilihan publik, dan perebutan kekuasaan secara damai yang dilembagakan serta kekuasaan publik untuk menjalankan kontrol kebijakan dapat berlaku. Meski merupakan wujud implementasi demokrasi, belum tentu setiap pemilihan demokratis. Sebagai esensi demokrasi, negara tak hanya 
sekedar menjalankan pemilihan umum sebagai sebuah mekanisme pergantian kekuasaan semata.

Pemilihan yang diselenggarakan haruslah terlaksana dengan demokratis, bermartabat dan berkualitas. Standar sebuah pemilihan disebut demokratis yang diterima oleh masyarakat internasional sebagaimana dalam buku panduan International IDEA (2002) memuat setidaknya 15 standar yang disepakati secara internasional, yaitu:

1) Penataan kerangka hukum;

2) Sistem pemilihan;

3) Penetapan batas wilayah daerah pemilihan, dan definisi batasan pemilihan;

4) Hak untuk memilih dan dipilih;

5) Lembaga penyelenggara pemilu;

6) Pendaftaran pemilih dan daftar pemilih;

7) Akses surat suara untuk partai politik dan kandidat;

8) Kampanye pemilu yang demokratis;

9) Akses media dan kebebasan berekspresi;

10) Pembiayaan dan pengeluaran kampanye;

11) Pemungutan Suara;

12) Penghitungan dan tabulasi suara;

13) Peran perwakilan partai politik dan kandidat;

14) Pemantau pemilu;

15) Kepatuhan penegakan hukum pemilu. Kelima belas poin standar tersebut selanjutnya menjadi pedoman di berbagai negara yang mempraktikkan pemilu sebagai mekanisme pergantian kekuasaan.

Surbakti dan Fitrianto (2015) juga merangkum standar internasional tentang pemilihan demokratis yang dielaborasi dalam delapan poin, yaitu:

1) Pemilihan yang dilaksanakan secara periodik dan berkala menurut undangundang;

2) Pemilihan yang sesungguhnya, artinya dilaksanakan dalam kondisi lingkungan sosial politik yang kondusif, sehingga terdapat jaminan partisipasi dan kompetisi yang terbuka;

3) Pemilihan yang bebas, berkaitan dengan hak kebebasan politik warga negara, berekspresi, berpendapat, memilih dan dipilih, berserikat dan sebagainya;

4) Pemilihan yang adil, menjamin kontestasi yang berkeadilan serta menjunjung kesetaraan;

5) Terdapat hak memilih dan dipilih semua warga negara yang memenuhi syarat berdasarkan undang-undang;

6) Hak pilih yang setara, artinya setiap pemilih memiliki nilai satu suara yang sama;

7) Jaminan kerahasiaan pilihan pemilih;

8) Penghitungan suara dan tabulasi suara yang jujur, prinsip ini mengharuskan penyelenggara pemilihan untuk menjalankan tugas secara profesional, jujur, efisien, akurat.

Kriteria lebih ringkas dikemukakan oleh Robert Dahl dalam tulisan Liando (2016). Bagi Dahl, parameter pemilihan suatu negara dapat disebut sebagai demokratis jika memenuhi kriteria berikut: terdapat pemilihan umum yang setiap warga memenuhi syarat memiliki hak untuk memilih dan dipilih secara bebas sesuai kehendak hati nuraninya; terdapat rotasi kekuasaan sehingga peluang 
pergantian kekuasaan selalu ada; transparansi rekrutmen politik yang membuat setiap warga negara yang memenuhi syarat memiliki kesempatan yang sama untuk dipilih dan mengikuti kompetisi; dan terdapat akuntabilitas atau pertanggungjawaban jabatan kepada publik.

Sementara menurut Sardini (2011), terdapat beberapa indikator untuk mengukur kualitas penyelenggaraan pemilihan, yaitu:

1) Memenuhi tujuan pemilihan untuk membentuk pemerintahan yang demokratis, kuat dan berlegitimasi;

2) Terdapat kompetisi yang sehat, partisipatif dan keterwakilan yang tinggi antara pemilih dengan yang dipilih dan melalui mekanisme akuntabilitas yang jelas;

3) Terdapat jadwal dan tahapan pemilihan yang dilaksanakan tepat waktu;

4) Pemilihan dilaksanakan dengan menjunjung asas-asas pemilihan: langsung, umum, bebas, rahasia, jujur dan adil serta dipatuhinya ketentuan peraturan perundang-undangan pemilihan.

Menilik berbagai kriteria yang telah dikemukakan di atas, untuk mewujudkan sebuah pemilihan yang demokratis merupakan sebuah tantangan tersendiri. Suswantoro (2015) menambahkan bahwa pemilihan yang demokratis dapat diwujudkan apabila terdapat integritas pada proses penyelenggaraan dan hasil pemilihan. Untuk mencapai pemilihan demokratis tersebut, dalam penyelenggaraannya harus memperhatikan ketentuan peraturan perundang-undangan dan menerapkan asas-asas pemilihan. Dimana berdasarkan Pasal 2 UU Nomor 1 Tahun 2015 tentang Penetapan Peraturan Pemerintah Pengganti UU (Perppu) Nomor 1 Tahun 2014 tentang Pemilihan Gubernur, Bupati, dan Walikota menjadi UU sebagaimana telah beberapa kali diubah, terakhir dengan UU Nomor 6 Tahun 2020 tentang Perppu Nomor 2 Tahun 2020 tentang Perubahan Ketiga atas UU Nomor 1 Tahun 2015 tentang Perppu Nomor 1 Tahun 2014 tentang Pemilihan Gubernur, Bupati dan Walikota menjadi Undang-Undang asasasas dalam Pemilihan secara demokratis antara lain langsung, umum, bebas, rahasia, jujur dan adil (luberjurdil).

Hal ini sejalan dengan apa yang ditekankan oleh Surbakti dan Nugroho (2015) bahwa asas penyelenggara pemilu merujuk pada seperangkat sistem nilai yang dikehendaki undang-undang untuk menghasilkan penyelenggara pemilu yang berintegritas. Adanya standar pemilihan demokratis sebagaimana diungkapkan sebelumnya, selanjutnya memunculkan berbagai macam hal yang harus dijamin penyelenggara pemilihan agar pemilihan yang dijalankan memiliki derajat demokratis yang tinggi. Tuntutan jaminan tersebut termasuk di dalamnya adalah adanya pengawasan proses pemilihan sehingga tidak ada penyelewengan atau pelanggaran yang terjadi.

\section{Perspektif Pengawasan}

Studi terkait pengawasan pemilihan cukup banyak dilakukan. Dalam masyarakat internasional lazim dikenal kegiatan pengawasan atau pemantauan 
pemilihan yang terbagi dalam tiga makna meski memiliki fungsi umum serupa, yaitu election observation, election monitoring dan election supervision. ACE Electoral Knowledge Network (2006) mendefinisikan election observation sebagai kegiatan mengumpulkan informasi penyelenggaraan pemilihan dan membuat penilaian terhadap informasi yang didapatkan. Sedangkan kegiatan election monitoring dilaksanakan oleh suatu organisasi/lembaga yang diberikan wewenang negara untuk mengamati proses pemilihan dan mengintervensi prosesnya jika terdapat ketentuan atau prosedur yang dilanggar. Election supervision didefinisikan sebagai kegiatan pengawasan dan audit proses penyelenggaraan pemilihan dengan sertifikasi keabsahan sebagian atau seluruh tahapan pemilihan.

Sementara itu, George R. Terry dalam kajian Syam (2021) memberikan definisi pengawasan sebagai sebuah tindakan evaluasi dan koreksi terhadap hasil yang dicapai agar sesuai dengan rencana.

Dengan demikian, poin utama tujuan pengawasan adalah untuk memastikan hal yang dilaksanakan sesuai dengan standar atau kriteria yang telah ditetapkan. Dalam proses electoral di Indonesia, pengemban tugas utama pengawasan pemilu adalah jajaran Badan Pengawas Pemilu (Bawaslu). Keberadaan lembaga pengawas ini antara lain adalah untuk menjamin perebutan kekuasaan melalui proses pemilihan dapat berlangsung secara beradab berdasarkan prosedur yang telah ditetapkan dengan berpedoman pada asas-asas tersebut di atas.
Lebih lanjut, Surbakti dan Nugroho (2015) menjelaskan bahwa kedudukan hukum pengawas pemilu memang terkait misi pencegahan dan pengawasan pemilu. Meskipun hal ini di luar kelaziman badan penyelenggara pemilu yang berlaku secara internasional, tetapi di Indonesia fungsi peradilan pemilihan dijalankan oleh Bawaslu. Sesuai UU Nomor 1 Tahun 2015 tentang Perppu Nomor 1 Tahun 2014 tentang Pemilihan Gubernur, Bupati, dan Walikota menjadi UU sebagaimana telah beberapa kali diubah, terakhir dengan UU Nomor 6 Tahun 2020 tentang Perppu Nomor 2 Tahun 2020 tentang Perubahan Ketiga atas UU Nomor 1 Tahun 2015 tentang Perppu Nomor 1 Tahun 2014 tentang Pemilihan Gubernur, Bupati dan Walikota menjadi UU, pengawasan penyelenggaraan pemilihan dilaksanakan oleh Bawaslu dan jajarannya. Meski sejatinya pengawasan pemilihan tidak hanya dilakukan oleh Bawaslu saja namun juga berbagai unsur masyarakat.

Pengawasan terhadap proses penyelenggaraan pemilihan yang dilakukan oleh unsur masyarakat acapkali disebut sebagai kegiatan pemantauan. Perbedaannya menurut Surbakti dan Fitrianto (2015) adalah kewenangan yang dimiliki pengawas untuk mengawasi seluruh proses penyelenggaraan pemilihan, mengintervensi proses saat terjadi pelanggaran dan menyatakan kesahihan tahapan pemilihan. Sedangkan pemantau memberikan pernyataan ada tidaknya permasalahan pada proses penyelenggaraan pemilihan. Pengertian ini sepadan dengan election monitoring dan 
election observation yang digagas ACE Electoral Knowledge Network.

Upaya kontrol terhadap proses penyelenggaraan pemilihan inilah yang dijalankan oleh jajaran pengawas, demikian halnya dengan peran pemantauan pemilihan yang dijalankan oleh masyarakat. Termasuk di dalam upaya pengontrolan tersebut adalah adanya strategi pencegahan terhadap potensi pelanggaran, pengawasan penyelenggaraan dan penindakan terhadap berbagai dugaan pelanggaran dalam proses penyelenggaraan pemilihan.

Syam (2021) dalam kajiannya mengenai lembaga pengawas pemilu, mendetailkan peran pengawasan yang dijalankan oleh Bawaslu menjadi pengawasan preventif dan represif. Pada pengawasan preventif yang bersifat struktural dan spesifik, terdapat jenis-jenis pelanggaran yang berpotensi terjadi sehingga dapat dilakukan pencegahan terlebih dahulu. Sedangkan pengawasan represif dilaksanakan setelah suatu keputusan memiliki akibat hukum. Penjelasan tersebut selaras dengan peran dan upaya yang dijalankan Bawaslu beserta jajarannya dalam setiap penyelenggaraan pemilihan melalui strategi pencegahan, pengawasan dan penindakan pelanggaran. Maka pengawasan yang dijalankan Bawaslu ini tidak sebatas pada prosedural semata namun juga substansi pemilihan itu sendiri.

\section{Hasil dan Pembahasan}

\subsection{Implementasi Penyelenggaraan}

Pengawasan Pilkada dengan Satu Paslon di Jawa Tengah

Di Jawa Tengah terdapat 7 Kabupaten/Kota yang telah menyelenggarakan pilkada dengan satu paslon. Kabupaten Pati pada Pilkada tahun 2017, kemudian jumlahnya meningkat saat Pilkada Tahun 2020 sebanyak 6 Kabupaten/Kota, yaitu Kota Semarang, Kabupaten Grobogan, Kabupaten Boyolali, Kabupaten Sragen, Kabupaten Wonosobo dan Kabupaten Kebumen. Meski secara umum penyelenggaraan pilkada tersebut berjalan dengan lancar, namun dalam dinamikanya di lapangan penyelenggaraan pengawasannya tidaklah selalu mudah.

Seperti yang terjadi di Kabupaten Kebumen, relawan kolom kosong mendeklarasikan diri dan melakukan beberapa aksi sosialisasi. Meskipun demikian, Badruzzaman, Koordinator Divisi PHL Bawaslu Kabupaten Kebumen mengaku tidak mengetahui struktur kepengurusan para relawan tersebut. la menghitung setidaknya sebanyak tiga kali para relawan datang beramai-ramai ke Bawaslu Kabupaten Kebumen atas nama "Mas Koko", dua kali datang untuk melaporkan dugaan pelanggaran.

Dalam laporan hasil pengawasan Pilkada Tahun 2020 Bawaslu Kabupaten Kebumen, aksi sosialisasi kolom kosong terjadi pada masa kampanye disertai dengan pemasangan alat peraga sosialisasi. Kemudian saat alat peraga sosialisasi tersebut hilang, dilaporkan ke Bawaslu Kabupaten Kebumen. Namun pelaporan tersebut tidak dapat ditindaklanjuti 
pengawas karena syarat materiil tidak terpenuhi sesuai regulasi penanganan pelanggaran pemilihan. Sehingga laporan diteruskan ke Kepolisian Resor Kebumen sebagai tindak pidana umum. Selain itu terdapat laporan masyarakat terkait kegiatan pendukung kolom kosong namun setelah ditelusuri pengawas, tidak ditemukan dugaan pelanggaran pemilihan. Kegiatan yang dilakukan oleh pendukung kolom kosong tersebut tidak dapat ditindak dengan regulasi pemilihan, karena kolom kosong bukanlah peserta pemilihan. Hal tersebut sebagaimana juga diungkapkan oleh Badruzzaman, sehingga kolom kosong tidak dapat diperlakukan seperti peserta pemilihan dalam penindakan dugaan pelanggaran oleh pengawas.

Sementara di Kabupaten Pati, dalam catatan tertulis Panwas (Panitia Pengawas) Kabupaten Pati pada tahun 2017, disebutkan bahwa pada penyelenggaraan pilkada tersebut, gesekan antarpendukung terjadi cukup sering dengan saling melaporkan ke Panwas setempat. Kegiatan berupa sosialisasi kotak kosong dan pemasangan alat peraga sosialisasi juga dilakukan oleh para pendukung kotak kosong saat masa kampanye. Di Kecamatan Dukuhseti dan Tambakromo, pada beberapa titik alat peraga tersebut ditertibkan oleh Satpol PP dengan alasan tidak adanya izin atau melanggar peraturan daerah setempat (Abhan dkk, 2017). Adapun untuk isi sosialisasi tersebut mengenai kritik terhadap paslon tunggal. Kegiatan yang dilakukan oleh para pendukung kotak kosong menimbulkan reaksi keras dari tim kampanye paslon yang dilanjutkan dengan melaporkannya kepada pengawas. Pada kasus lain, saat panwas menangani dugaan pelanggaran politik uang, selain terbatas oleh waktu pemeriksaan dugaan pelanggaran, situasi dan kondisi yang dialami panwas juga cukup mencekam. Dijelaskan bahwa selama proses pemeriksaan dugaan pelanggaran politik uang yang dilakukan oleh panwas, massa pendukung kotak kosong yang menjadi pelapor memantau langsung dan berkumpul di kantor panwas. Selanjutnya pada hari terakhir sebelum pemungutan suara, massa pendukung paslon turut datang ke kantor panwas dan hampir terjadi bentrokan massa antarpendukung. Hal tersebut yang menjadi kendala bagi pengawas. Menurut Achwan, yang saat itu menjadi Koordinator Divisi PHL Panwas Kabupaten Pati Tahun 2017, kendala terbesar yang dialami jajaran pengawas adalah tidak adanya regulasi yang mengatur tentang aktivitas pendukung kolom kosong. Meskipun demikian, setiap tindakan yang diambil jajarannya telah dikonsultasikan terlebih dahulu ke Bawaslu Provinsi Jawa Tengah dan telah diupayakan sesuai dengan aturan yang berlaku.

Peristiwa serupa terjadi di Kabupaten Wonosobo pada Pilkada Tahun 2020. Masyarakat yang menjadi pendukung kolom kosong melakukan pemasangan alat peraga sosialisasi. Namun saat dilakukan penertiban, kewenangan jajaran pengawas hanyalah menindak alat peraga yang melanggar yang dipasang oleh tim paslon. Sedangkan untuk alat peraga pendukung kolom kosong diteruskan ke pemerintah daerah (Satpol PP). Ketika jajaran Satpol PP tidak segera bertindak, masyarakat menilai 
Bawaslu Kabupaten Wonosobo tidak tegas dan tebang pilih.

Beberapa peristiwa tersebut merupakan sebagian dinamika yang dihadapi jajaran pengawas di lapangan. Pada penyelenggaraan pengawasan pilkada dengan satu paslon di Jawa Tengah didapati pola-pola yang muncul dari implementasi penyelenggaraannya sebagai berikut:

1) Pada sejumlah daerah pilkada dengan satu paslon, terdapat relawan kolom kosong. Bahkan di sebagian kabupaten/kota tersebut, relawan kolom kosong juga melakukan aktivitas pergerakan. Seperti pada penyelenggaraan Pilkada tahun 2017 di Kabupaten Pati, dan Pilkada Tahun 2020 di Kabupaten Wonosobo, Kabupaten Kebumen, Kabupaten Sragen, dan Kota Semarang. Gerakan dari para relawan ini berupa aksi sosialisasi, meng"kampanye"kan kolom kosong sampai memasang alat peraga sosialisasi.

2) Sebanyak lima daerah pilkada dengan satu paslon, relawan kolom kosongnya tidak memiliki struktur kepengurusan, kecuali di Kabupaten Pati dan Kabupaten Wonosobo. Di Kabupaten Pati, berdasarkan informasi dari Achwan, Koordinator Divisi PHL Panwas Kabupaten Pati Tahun 2017, struktur kepengurusan tersebut bahkan sampai ke tingkat desa. Sedangkan di Kabupaten Wonosobo, relawan kolom kosong mendeklarasikan diri sebagai Tim Relawan Barisan Pejuang Kotak Kosong (Baju Koko). Struktur kepengurusannya pun telah disusun secara jelas dan beberapa kali melakukan aksi dukungan. Dalam pernyataan yang dideklarasikan, Baju Koko ini menolak pemilihan yang hanya ada satu paslon. Bagi mereka, hal tersebut dianggap sebagai salah satu bentuk pengebirian demokrasi dan arogansi kekuasaan.

3) Sosialisasi terkait adanya pilihan kolom kosong yang dilakukan oleh KPU Kabupaten/Kota masih dianggap belum optimal. Sosialisasi tersebut sebagian besar dilakukan dengan tatap muka, dalam acara-acara sosialisasi yang dilakukan oleh KPU Kabupaten/Kota.

4) Tingkat Partisipasi Masyarakat di Kabupaten/Kota yang hanya terdapat satu paslon dalam Pilkada 2017 dan 2020 yang cukup rendah dibandingkan target yang ditetapkan oleh KPU. Tingkat partisipasi masyarakat di lima daerah pilkada dengan satu paslon berada di rentang 63\% hingga 68\%, kecuali Kabupaten Sragen yang mencapai $73,86 \%$ dan Kabupaten Boyolali $89,85 \%$.

5) Perolehan Suara Kolom Kosong cukup tinggi di Kabupaten Kebumen dan Kabupaten Wonosobo pada Pilkada Tahun 2020. Di Kabupaten Kebumen, perolehan suara kolom kosong mencapai 39,17\%; di Kabupaten Wonosobo 36,28\%. Sementara di empat Kabupaten/Kota lainnya perolehan kolom kosong dalam rentang $4 \%$ hingga $19,77 \%$. Di Kabupaten Pati pada Tahun 2017 
kotak kosong memperoleh sekitar $25,49 \%$ suara.

6) Hampir semua daerah yang menyelenggarakan pilkada dengan satu paslon terdapat petahana yang maju kembali, kecuali di Kabupaten Wonosobo. Komposisinya bervariasi, ada yang petahana Bupati, petahana Wakil Bupati, maupun sepasang petahana yang maju kembali.

Dalam pilkada dengan satu paslon Tahun 2017 di Kabupaten Pati, petahana yang maju merupakan Bupati. Untuk penyelenggaraan pilkada dengan satu paslon Tahun 2020, di Kabupaten Grobogan dan Sragen yang maju kembali adalah petahana Bupati. sedangkan di Kabupaten Kebumen dan Boyolali petahana yang maju adalah Wakil Bupati. Hanya di Kota Semarang yang sepasang petahana-nya maju bersama.

7) Tingkat keterwakilan perempuan calon kepala daerah pada pilkada dengan satu paslon di Jawa Tengah cukup rendah. Dari total 14 calon, hanya 4 calon yang merupakan perempuan (28,57\%). Dua calon bupati dan merupakan petahana, satu calon wakil walikota petahana, dan satu calon wakil bupati bukan petahana.

8) Dukungan partai politik atau gabungan partai politik juga mempengaruhi munculnya paslon tunggal ini. Hampir di semua Pilkada Kabupaten/Kota dengan calon tunggal, paslon yang maju memiliki tingkat dukungan partai politik atau gabungan partai politik yang tinggi. Di Kabupaten Kebumen dan Kota Semarang, dukungan partai politik mencapai $100 \%$. Untuk Kabupaten Grobogan 98\%, Kabupaten Pati 92\%, Kabupaten Boyolali dan Wonosobo hanya $77,78 \%$ dan Kabupaten Sragen 64\%.

9) Jumlah pelanggaran pilkada tidak dipengaruhi jumlah paslon yang berkompetisi. Untuk Pilkada Tahun 2020, jumlah pelanggaran paling banyak justru ada di Kota Semarang yang merupakan salah satu daerah pilkada dengan satu paslon. Sedangkan pada Pilkada Tahun 2017, Kabupaten Pati yang juga merupakan daerah penyelenggara pilkada dengan satu paslon, menduduki peringkat pertama dalam jumlah dugaan pelanggaran, yaitu sejumlah 108 dugaan pelanggaran yang ditangani pengawas. Hal ini sesuai dalam catatan pengawasan Bawaslu Provinsi Jawa Tengah, yang mencatat pada Pilkada tahun 2017 jumlah dugaan pelanggaran pilkada paling tinggi justru terdapat di daerah penyelenggara pilkada dengan satu paslon Kabupaten Pati (Purnomo dkk., 2017).

10) Tidak semua Kabupaten/Kota yang menyelenggarakan pilkada dengan satu paslon terdapat lembaga pemantau. Kekosongan pemantau terjadi di Kabupaten Wonosobo untuk Pilkada Tahun 2020 dan di Kabupaten Pati saat Pilkada Tahun 2017.

11) Terdapat kekurangcermatan penyelenggara teknis dalam persiapan penyelenggaraan pilkada dengan satu paslon. Berdasar laporan pengawasan 
penyelenggaraan Pilkada tahun 2020 dari Bawaslu Kota Semarang, pada tahapan distribusi perlengkapan pemilihan, jajaran pengawas menemukan tulisan yang tidak tepat dalam bilik suara yang diproduksi. Tulisan itu berbunyi "Coblos Surat Suara Pada Kolom Yang Berisi No.Urut/Pas Foto/Nama Pasangan Calon". Bilik suara tersebut memang pengadaan dan distribusinya dilaksanakan oleh KPU Republik Indonesia, namun untuk daerah dengan calon tunggal yang akan berkontestasi seperti Kota Semarang, kalimat panduan dalam bilik suara tersebut tidak tepat dan dapat dinilai mengarahkan pemberian suara kepada paslon.

Dijelaskan oleh Nining, Koordinator Divisi PHL Bawaslu Kota Semarang, bahwa sepertinya terjadi kekurangtelitian dalam produksi tersebut karena beberapa kabupaten/kota lain yang juga memiliki paslon tunggal di Jawa Tengah mulanya juga menerima bilik suara serupa. Hal tersebut dapat diatasi setelah Bawaslu Kota Semarang mengirim surat saran perbaikan dan KPU Kota Semarang segera merespon untuk menutup tulisan pada bilik tersebut dengan stiker putih. Sehingga tidak mengganggu jalannya tahapan penyelenggaraan.

\subsection{Pemetaan Masalah dalam Pilkada dengan Satu Paslon}

Berdasarkan pola-pola di atas, permasalahan pokoknya bersumber dari kekurangan regulasi yang memayungi pelaksanaan pemilihan dengan satu paslon, terlebih lagi untuk mengatur lebih lanjut tentang aktivitas pendukung kolom kosong, membuat penyelenggara pengawas kesulitan dalam melaksanakan tugasnya. Mencermati Peraturan Komisi Pemilihan Umum Nomor 14 Tahun 2015 tentang Pemilihan Gubernur dan Wakil Gubernur, Bupati dan Wakil Bupati, dan/atau Walikota dan Wakil Walikota dengan Satu Pasangan Calon sebagaimana telah diubah terakhir kali dengan PKPU Nomor 20 Tahun 2020 tentang Perubahan Kedua atas Peraturan Komisi Pemilihan Umum Nomor 14 Tahun 2015 tentang Pemilihan Gubernur dan Wakil Gubernur, Bupati dan Wakil Bupati, dan/atau Walikota dan Wakil Walikota dengan Satu Pasangan Calon, kehadiran kolom kosong sebagai "kontestan" dalam pilkada dengan satu paslon masih diakomodasi terbatas.

Salah satu poin yang telah ditambahkan dalam regulasi pemilihan hanyalah terkait "konsekuensi" jika perolehan suara kolom kosong lebih tinggi. Secara singkat, konsekuensi tersebut adalah dengan penyelenggaraan pemilihan kembali pada pemilihan serentak periode berikutnya. Sementara kekosongan jabatan tersebut akan diisi oleh penjabat gubernur, bupati atau walikota.

Gerakan-gerakan dari pendukung kolom kosong yang terjadi di beberapa daerah penyelenggara pemilihan paslon tunggal yang telah diuraikan sebelumnya, menunjukkan jika masih terdapat masyarakat pemilih yang tidak menginginkan pemilihan hanya diikuti oleh satu paslon. Dari sisi penyelenggara teknis, tentu sudah membuka ruang pada tahap pencalonan melalui jalur lain selain lewat 
partai politik, yakni melalui jalur perseorangan. Sebetulnya melalui jalur ini, masyarakat diberikan keleluasaan untuk mencalonkan diri tanpa terlibat partai politik dengan modal basis dukungan dan sumber daya sendiri. Namun disisi lain, dalam aturan teknisnya, syarat untuk maju melalui jalur perseorangan menurut penulis masih terlalu berat.

Sehingga sebagian masyarakat memilih melalui gerakan pendukung kolom kosong yang dianggap lebih "cepat", "murah" dan pada beberapa aspek "efektif" melawan paslon tunggal. Meskipun hal tersebut juga dilakukan dengan bersembunyi di balik celah kekosongan regulasi.

Pada penelitian yang telah dilakukan oleh Hikmania (2019) dengan judul Pergulatan Konsep Contested Election dan Uncontested Election (Studi Kasus Pilkada Kabupaten Pati Tahun 2017), bangunan kelembagaan serta desain teknis penyelenggaraan pilkada secara umum masih dibuat dengan "mereplikasi" jenis pemilu kontestasi. Artinya, proses penyelenggaraan dan tahapannya sama saja dengan penyelenggaraan pemilihan yang memiliki kontestan minimal dua paslon. Akan tetapi perlakuan seperti ini implikasinya adalah melahirkan kompetisi semu dan ketidaksetaraan antara paslon tunggal dengan kotak kosong.

Konsep tersebut menjadikan ambiguitas status kolom kosong dan membuat jajaran pengawas di lapangan gamang dalam memfasilitasi maupun melakukan penindakan terhadap aktivitas kolom kosong beserta pendukung atau relawannya. Kegamangan ini terutama sebagaimana dipaparkan sebelumnya bahwa para relawan kolom kosong seringkali melakukan aktivitas yang serupa dengan tim kampanye/peserta pemilihan namun secara formal tidak dapat diperlakukan sama.

Koordinator Divisi PHL Bawaslu Kabupaten Boyolali, Rubiyanto, menyampaikan jika sebaiknya relawan atau pendukung kolom kosong perlu diatur dalam regulasi karena pengawas tidak bisa menertibkan kegiatan relawan kolom kosong. Senada dengan Achwan, Koordinator Divisi PHL Panwas Kabupaten Pati Tahun 2017, selain aturan tersebut, juga diperlukan mekanisme pengawasan dan penindakan yang dapat menjadi pedoman jajaran pengawas.

Ketiadaan regulasi tersebut juga dirasa menyulitkan oleh Daniel, Koordinator Divisi PHL Bawaslu Kabupaten Wonosobo, meski di Kabupaten Wonosobo relawan dan pendukung kolom kosong melakukan deklarasi dan membentuk struktur kepengurusan. Namun hal tersebut hanya memudahkan dari sisi pencegahan dan pengawasannya saja. Jika terjadi dugaan pelanggaran dalam aktivitas kolom kosong tersebut maka pengawas tidak dapat menindak sebagai pelanggaran pemilihan, karena kolom kosong bukan sebagai peserta pemilihan.

Celah kekosongan regulasi ini bila terus didiamkan akan menjadi persoalan yang terus berulang dan dapat bereskalasi menjadi konflik yang meluas. Beberapa permasalahan terkait celah kekosongan regulasi tersebut antara lain:
a) Kedudukan
pendukung/relawan
kolom kosong memiliki banyak 
permasalahan tersendiri. Pendukung kolom kosong pada beberapa daerah memiliki struktur kepengurusan, seperti di Kabupaten Wonosobo, namun tidak ada aturan yang menyebut bagaimana melegalkan mereka sebagai pendukung kolom kosong, untuk dapat melakukan aktivitas resmi layaknya pendukung paslon. Jika harus mendaftarkan diri sebagai tim pendukung, persoalan selanjutnya adalah ke lembaga apa mereka mendaftarkan diri? Kemudian jika mendaftarkan diri bagaimana kedudukan tim pendukung kolom kosong ini, apakah dianggap sama dengan tim kampanye atau dianggap sebagai pemantau? Jika dianggap sama dengan tim kampanye, tentu memiliki konsekuensi untuk menyusun pelaporan lainnya sebagaimana peserta pemilihan yang berkontestasi. Maka karena kedudukan pendukung kolom kosong ini masih abu-abu, pengawas juga memiliki kesulitan memperlakukan pendukung ini sebagaimana tim kampanye, pemantau pemilihan atau hanya sebagai warga negara yang memiliki hak pilih.

b) Dalam aturan teknisnya, kegiatan kampanye untuk pemilihan dengan satu paslon dilakukan oleh KPU Provinsi/Kabupaten/Kota, pasangan calon dan atau tim kampanye. Namun untuk kolom kosong, meski dianggap sebagai "lawan" atau salah satu "kontestan" pemilihan, namun tidak ada keterangan dapat melakukan kegiatan yang sama. Sehingga pada praktiknya pun kolom kosong tidak dapat dianggap boleh atau bisa melakukan kampanye. Bahkan jika harus disosialisasikan oleh penyelenggara teknis, penyelenggara teknis hingga saat ini tidak menyediakan alat peraga sosialisasi atau bahan sosialisasi untuk kolom kosong. Sehingga meskipun di beberapa daerah para pendukung kolom kosong ini melakukan sosialisasi, "berkampanye" atau memasang alat sosialisasi kolom kosong, maka pengawas tidak dapat menindak dengan regulasi pemilihan.

c) Hal yang paling sering ditemukan di Kabupaten/Kota yang menyelenggarakan pilkada dengan satu paslon adalah permasalahan Alat Peraga Kampanye (APK) dan Bahan Kampanye (BK). Dalam pemilihan, posisi APK dan BK untuk paslon dan kolom kosong tidak berimbang. Baik secara jumlah, maupun dalam melakukan penanganan dugaan pelanggarannya. Jumlah APK dan BK paslon dibatasi sesuai regulasi, namun tidak disebutkan untuk kolom kosong. Selain itu, di daerah dengan paslon tunggal, terjadi fenomena munculnya APK/BK paslon yang secara eksplisit menyinggung kolom kosong dan sebaliknya, ataupun terjadi perusakan/hilangnya alat peraga salah satu pihak. Keduanya sulit ditindak pengawas karena tidak adanya regulasi pemilihan terkait hal itu. Jika terdapat laporan dari pendukung kolom kosong pun maka pengawas hanya dapat menangani laporan 
tersebut sebagai laporan dari warga negara yang memiliki hak pilih, namun tidak dapat disebut sebagai dugaan pelanggaran pemilihan karena yang dirusak/hilang bukanlah APK/BK sebagaimana yang ditetapkan dalam aturan KPU. Seperti yang terjadi di Kabupaten Kebumen yaitu perusakan atau hilangnya "APK/BK" atau alat peraga sosialisasi kolom kosong. Persoalan ini juga berujung pada ketentuan pada masa tenang dimana seluruh atribut kampanye dan sosialisasi harus diturunkan, sementara tidak ada ketentuan mengenai "APK/BK" ataupun bahan sosialisasi yang berasal dari para pendukung atau relawan kolom kosong.

d) Selanjutnya terkait dengan dana kampanye, karena aktivitas pendukung kolom kosong yang juga serupa dengan pendukung paslon. Di Kabupaten Pati, hal ini juga menimbulkan reaksi dari pendukung paslon. Jika kolom kosong merupakan lawan dari paslon atau sebagai kontestan pemilihan, maka seharusnya juga wajib untuk melaporkan dana kampanye, seperti halnya peserta pemilihan. Termasuk jumlah maksimal sumbangan dana kampanye, pihak-pihak yang dapat memberikan sumbangan dana kampanye, laporan awal dana kampanye, laporan penerimaan dan pengeluaran dana kampanye serta melalui proses audit dana kampanye. Hal ini mungkin cukup berat untuk para pendukung kolom kosong, karena dapat dipastikan terbentuknya relawan dan pendukung kolom kosong ini setelah masa penetapan paslon oleh keputusan penyelenggara teknis KPU. Selain dari segi waktu pembentukan tim pendukung yang sangat sempit dibandingkan tim pemenangan paslon dari jalur partai politik, manajemen pengelolaan dan pelaporannya juga membutuhkan orang yang berkompeten untuk mengurusnya.

e) Saksi pemungutan suara dan rekapitulasi penghitungan suara untuk kolom kosong juga diperlukan. Karena kolom kosong diperlakukan seperti kontestan dalam pemilihan, maka suara yang diperoleh kolom kosong adalah sah dalam pemilihan. Jika terjadi perselisihan hasil pemilihan, kolom kosong harus memiliki saksi sebagai legal standing. Meskipun pada Pilkada 2020, KPU memperbolehkan pemantau untuk dapat memasuki TPS saat proses penghitungan dan rekapitulasi penghitungan suara. Jika hal tersebut diwakilkan kepada pemantau pemilihan, tidak semua daerah yang melaksanakan pemilihan dengan paslon tunggal memiliki pemantau. Di Jawa Tengah saja, dari tujuh daerah yang pernah melaksanakan Pilkada dengan satu paslon, dua kabupaten di antaranya tidak terdapat pemantau.

\subsection{Perspektif Pengawasan Pilkada dengan Satu Paslon}

Mengacu standar pemilihan demokratis terkait adanya kerangka hukum, diakui atau tidak, kerangka hukum 
pemilihan di Indonesia termasuk tidak stabil karena mengikuti konstelasi politik yang terjadi. Seringnya perubahan pada regulasi pemilihan, termasuk sebagai dampak dari pengujian MK, di lain sisi membuat penyelenggara pemilihan harus bergerak cepat menyusun aturan teknis sebagai payung hukum. Hal ini selanjutnya menjadi memberatkan kala penyelenggara pemilihan yang kemudian membuat penafsiran teknis dari putusan tersebut, sebagaimana yang diuraikan dalam kajian Hikmania (2019).

Pada penyelenggaraan Pilkada dengan satu paslon, pengawas menghadapi cukup banyak tantangan tanpa adanya payung hukum maupun pedoman teknis rinci terkait yang dapat menegaskan tindakan pengawas di lapangan dalam melaksanakan tugas. Persoalan pokok dalam pilkada dengan satu paslon yang mengerucut pada tiga hal yaitu ambiguitas status, posisi dan fasilitasi kolom kosong turut membawa kompleksitas pengawasan dan penindakan dugaan pelanggaran.

Pada beberapa kasus misalnya, di Kabupaten Pati dan Kabupaten Wonosobo, persoalan fasilitasi kolom kosong terkait alat peraga sosialisasi, dan aktivitas sosialisasi yang menyerupai kampanye kolom kosong membawa dampak langsung terhadap kredibilitas pengawas. Jika menilik indikator ukuran kualitas pemilihan, bahwa perlu kompetisi yang sehat, partisipatif dan keterwakilan yang tinggi antara pemilih dengan yang dipilih dan melalui mekanisme akuntabilitas yang jelas, peran pengawas menjadi utama dilihat dari kerangka menjaga penyelenggaraan pemilihan yang langsung, umum, bebas, rahasia, jujur dan adil.

Namun merujuk pada definisi kampanye dalam undang-undang pemilihan kepala daerah, bahwa kampanye merupakan kegiatan untuk meyakinkan pemilih dengan menawarkan visi, misi dan program calon kepala daerah, kolom kosong dianggap tidak dapat berkampanye. Sehingga kegiatan kampanye hanya dapat dilakukan oleh partai politik dan/atau paslon serta difasilitasi oleh KPU.

Karena tidak dapat berkampanye sendiri, secara normatif kolom kosong hanya memiliki ruang "kampanye" melalui APK maupun BK yang difasilitasi oleh KPU. Persoalannya di lapangan kemudian muncul berbagai alat peraga sosialisasi yang diinisiasi oleh para pendukung atau relawan kolom kosong. Akan tetapi karena adanya perbedaan status hukum antara alat peraga kampanye dan alat peraga sosialisasi tersebut tentu menimbulkan adanya perbedaan perlakuan terhadapnya.

Sebagai contoh misalnya terdapat laporan dugaan pelanggaran, seperti yang terjadi di Kabupaten Kebumen terkait hilangnya alat peraga sosialisasi pendukung kolom kosong, karena bukan termasuk dugaan pelanggaran pemilihan, pengawas kemudian hanya dapat meneruskan laporan tersebut kepada instansi berwenang.

Di lain sisi, bahwa persebaran alat peraga sosialisasi ini tidak terikat secara hukum dalam ketentuan tempat dan lokasi yang ditentukan dalam pemasangan APK oleh KPU. Sehingga persebarannya 
seringkali juga cenderung tidak "terkendali".

Persoalan lainnya adalah adanya relawan atau pendukung kolom kosong yang melakukan aktivitas pengumpulan masa ataupun pertemuan tatap muka yang serupa dengan aktivitas kampanye. Misalnya sekalipun tidak terdapat ajakan secara langsung untuk mencoblos kolom kosong tetapi dengan mengatasnamakan relawan kolom kosong mengumpulkan massa dalam jumlah banyak untuk melakukan jalan sehat, sepeda bersama atau kegiatan pengumpulan massa lainnya seperti di Kabupaten Pati. Situasi demikian seringkali menyulitkan pengawas di lapangan dikarenakan tidak ada ketentuan yang mengatur. Sehingga dalam hal ini pengawas dianggap tidak mampu bertindak tegas menghadapi kegiatan pendukung kolom kosong.

Meskipun demikian, upaya pengawasan dengan penerapan mekanisme pencegahan juga telah diupayakan jajaran pengawas pada setiap tahapan pemilihan, baik melalui koordinasi dengan seluruh stakeholder maupun penyampaian imbauan. Strategi ini sebagaimana yang disebut sebagai pengawasan preventif, di mana jajaran pengawas telah memetakan kerawanan terhadap potensi-potensi pelanggaran yang akan terjadi, sehingga dapat melakukan upaya pencegahan.

Namun menilik konsep keadilan untuk kompetisi dalam pemilihan, seharusnya konsep keadilan ini mewujud dalam fasilitasi yang diberikan oleh penyelenggara pemilihan. Bagi pengawas, perlunya kejelasan batasan pihak-pihak yang dapat melakukan aktivitas sosialisasi kolom kosong, pemasangan dan penertiban alat peraga sosialisasi kolom kosong, akan menegaskan tugas pengawas dalam menjalankan fungsi pengawasan, fasilitasi penerimaan laporan dugaan pelanggaran dan fungsi penindakan sebagaimana mestinya. Penegasan ini misalnya dengan menetapkan kepengurusan relawan kolom kosong setelah melalui proses pendaftaran dengan persyaratan administrasi tertentu melalui tahap verifikasi. Dimana relawan kolom kosong tersebut pada akhirnya dapat memiliki status hukum yang sejajar dengan tim kampanye berikut kewajiban yang menyertai status tersebut. Adapun jika memang tidak ada relawan yang memenuhi persyaratan maka selanjutnya dapat dilakukan tindakan dan sanksi tegas yang terukur terhadap setiap bentuk dan tindakan yang mengatasnamakan kolom kosong mulai dari sanksi administrasi hingga pidana pemilihan misalnya apabila diperlukan.

\section{Simpulan}

Beberapa permasalahan yang muncul berdasarkan implementasi penyelenggaraan pilkada dengan satu paslon di Jawa Tengah sebagaimana telah dijelaskan sebelumnya terutama terkonsentrasi pada persoalan mengenai ambiguitas status, posisi dan fasilitasi kolom kosong. Persoalan tersebut pada akhirnya juga berimbas pada munculnya kompleksitas baik penyelenggaraan teknis maupun upaya pengawasan serta penindakan atas laporan dugaan pelanggaran dalam penyelenggaraan pilkada dengan satu pasangan calon. 
Beberapa alternatif rekomendasi dalam menyikapi persoalan ini antara lain dapat dilakukan dengan penyempurnaan desain penyelenggaraan pemilihan dengan satu pasangan calon, misalnya melalui perubahan perspektif hukum ataupun penguatan status terhadap kedudukan kolom kosong perlu dilakukan guna meningkatkan derajat kompetisi dan nilai keadilan substansial dalam rangka mewujudkan pemilihan yang demokratis. Penguatan status tersebut misalnya melalui penetapan kepengurusan relawan kolom kosong yang dapat dilakukan oleh penyelenggara teknis KPU, sehingga relawan kolom kosong memiliki legal standing dan status hukum yang jelas.

Hal ini penting guna menjamin legitimasi serta integritas proses dan hasil pemilihan yang pada gilirannya akan meningkatkan kepercayaan masyarakat terhadap kepemimpinan politik hasil pemilihan. 


\section{DAFTAR PUSTAKA}

Abhan, Asep Mufti \& Achwan. (2017). Pasangan Calon Melawan Kolom Kosong (Potret Pemilihan Bupati dan Wakil Bupati Pati Tahun 2017. Semarang: CV. Rafi Sarana Perkasa.

ACE Electoral Knowledge Network (2006, December 4). Election observation, monitoring, and supervision. Diakses dari https://aceproject.org/electoraladvice/archive/questions/replies/234934798

Ekowati, E. Y. (2019). Pragmatisme Politik: Antara Koalisi, Pencalonan, dan Calon Tunggal Dalam Pilkada. Transformative, 5(1), hlm. 16-37. http://dx.doi.org/10.21776/ub.transformative.2019.005.01.2

Fahmi, K. (2016). Menelusuri Konsep Keadilan Pemilihan Umum Menurut UUD 1945. Cita Hukum, 4(20), hlm. 167-186. http://dx.doi.org/10.15408/ich.v4i2.4098

Hikmania, Y. S. (2019). Pergulatan Konsep Contested Election dan Uncontested Election (Studi Kasus Pilkada Kabupaten Pati Tahun 2017). Kompilasi Ringkasan Tesis Tata Kelola Pemilu, 1.

International IDEA. (2002). Standar-standar Internasional untuk Pemilihan Umum: Pedoman Peninjauan Kembali Kerangka Hukum Pemilu. Jakarta: International IDEA.

Laporan Akhir Hasil Pengawasan Pemilihan Bupati dan Wakil Bupati Tahun 2020 Bawaslu Kabupaten Boyolali

Laporan Akhir Hasil Pengawasan Pemilihan Bupati dan Wakil Bupati Tahun 2020 Bawaslu Kabupaten Grobogan

Laporan Akhir Hasil Pengawasan Pemilihan Bupati dan Wakil Bupati Tahun 2020 Bawaslu Kabupaten Kebumen

Laporan Akhir Hasil Pengawasan Pemilihan Bupati dan Wakil Bupati Tahun 2020 Bawaslu Kabupaten Sragen

Laporan Akhir Hasil Pengawasan Pemilihan Bupati dan Wakil Bupati Tahun 2020 Bawaslu Kabupaten Wonosobo

Laporan Akhir Hasil Pengawasan Pemilihan Walikota dan Wakil Walikota Tahun 2020 Bawaslu Kota Semarang

Liando, D. M. (2016). Pemilu dan Partisipasi Politik Masyarakat (Studi pada Pemilihan Anggota Legislatif dan Pemilihan Presiden dan Calon Wakil Presiden di Kabupaten Minahasa Tahun 2014). Jurnal LPPM Bidang EkoSosBudKum, 3(2), hlm. 14-28.

Marijan, Kacung. (2010). Sistem Politik Indonesia Konsolidasi Demokrasi Pasca-Orde Baru. Jakarta: Prenadamedia Group.

Muttaqin, E. F. (2014). Implikasi Yuridis Keikutsertaan Calon Perseorangan Dalam Pelaksanaan Pemilihan Umum Kepala Daerah Dan Wakil Kepala Daerah. Jurnal Konstitusi, hlm. 1-33.

Nazriyah, R. (2016). Calon Tunggal dalam Pilkada Serentak Tahun 2015 terhadap Putusan Mahkamah Konstitusi Nomor 100/PUU-XIII/2015. Jurnal Konstitusi, 13(2), hlm. 379-405. 
Pamungkas, Sigit. (2010). Pemilu, Perilaku Pemilih dan Kepartaian. Yogyakarta: Institute for Democracy and Welfarism.

Peraturan Komisi Pemilihan Umum Nomor 14 Tahun 2015 tentang Pemilihan Gubernur dan Wakil Gubernur, Bupati dan Wakil Bupati, dan/atau Walikota dan Wakil Walikota dengan Satu Pasangan Calon sebagaimana telah diubah terakhir kali dengan PKPU Nomor 20 Tahun 2020 tentang Perubahan Kedua atas Peraturan Komisi Pemilihan Umum Nomor 14 Tahun 2015 tentang Pemilihan Gubernur dan Wakil Gubernur, Bupati dan Wakil Bupati, dan/atau Walikota dan Wakil Walikota dengan Satu Pasangan Calon.

Prayudi, Ahmad Budiman \& Aryojati Ardipandanto. (2017). Dinamika Politik Pilkada Serentak. Jakarta: Pusat Penelitian Badan Keahlian DPR RI.

Putusan Nomor 5/PUU-V/2007

Putusan Nomor 100/PUU-XIII/2015

Purnomo, Teguh, dkk. (2017). Catatan Pengawasan Pemilu di Jawa Tengah: Memori Jabatan Anggota Bawaslu Jawa Tengah Periode 2012-2017. Semarang: Bawaslu Provinsi Jawa Tengah.

Rahmanto, T. Y. (2018). Calon Tunggal dalam Perspektif Hak Memilih dan Dipilih di Provinsi Banten. Jurnal HAM, 9(2), hlm. 103-119. http://dx.doi.org/10.30641/ham.2018.9.103$\underline{120}$

Sardini, Nur Hidayat. (2011). Restorasi Penyelenggaraan Pemilu di Indonesia. Yogyakarta: Fajar Media Press.

Shapiro, lan. (2006). Asas Moral dalam Politik. Jakarta: Kedutaan Besar Amerika Serikat Jakarta bekerja sama dengan Freedom Institute dan Yayasan Obor Indonesia.

Strauss, Anselm \& Juliet Corbin. (2003). Dasar-dasar Penelitian Kualitatif: Tata Langkah dan Teknik-teknik Teoritisasi Data. Yogyakarta: Pustaka Pelajar.

Surbakti, Ramlan \& Hari Fitrianto. (2015). Transformasi Bawaslu dan Partisipasi Masyarakat dalam Pengawasan Pemilu. Jakarta: Kemitraan bagi Pembaruan Tata Pemerintahan.

Surbakti, Ramlan \& Kris Nugroho. (2015). Studi tentang Desain Kelembagaan Pemilu yang Efektif. Jakarta: Kemitraan bagi Pembaruan Tata Pemerintahan.

Susanti, Nining dkk. (2021). Pengawasan dalam Angka: Pilkada Kota Semarang 2020. Semarang: Bawaslu Kota Semarang.

Suswantoro, Gunawan. (2015). Pengawasan Pemilu Partisipatif. Jakarta: Erlangga.

Syam, R. (2021). Penguatan Lembaga Pengawas Pemilihan Umum : Analisis Yuridis Normatif. Jurnal Etika \& Pemilu, 7(1), hlm. 59-77.

Tanjung, M. A. \& Saraswati, R. (2019). Calon Tunggal Pilkada kurangi Kualitas Demokrasi (Kajian Putusan Mahkamah Konstitusi Nomor 100/PUU-XIII/2015). Jurnal Yudisial, 12(3), hlm.269-285. http://dx.doi.org/10.29123/jy.v12i3.319

Undang-Undang Republik Indonesia Nomor 6 tahun 2020, Tentang Penetapan Peraturan Pemerintah Pengganti Undang-Undang Nomor 2 Tahun 2020 Tentang Perubahan Ketiga Atas Undang-Undang Nomor 1 Tahun 2015 Tentang Penetapan Peraturan Pemerintah 
Pengganti Undang-Undang Nomor 1 Tahun 2014 Tentang Pemilihan Gubernur, Bupati, dan Walikota Menjadi Undang-Undang.

Widyasari, A., Dewi, R. A., Rengganis, M. S. (2019). Gerakan Politik Pendukung Kotak Kosong: Keterlibatan Civil Society dalam Pilkada Kabupaten Pati Tahun 2017. Jurnal PolGov, I (1), hlm.89-119. https://doi.org/10.22146/polgov.v1i1.48307 